\title{
America's fresh start
}

The next US president will lead the country back onto the world stage in many arenas, including science.

M ost of America's leading scientific establishment spent this spring agitating for a 'science debate' between the presidential candidates. Not surprisingly, the debate never happened; science has rarely, if ever, been a major issue in US presidential campaigns. But its supporters shouldn't lament that fact. Many of the issues that are central to the current campaign have a strong science component (see page 442 ).

The most obvious example is climate change. No matter who wins, the current administration's eight-year-long pattern of denial and foot-dragging will end. Both McCain and Obama have pledged to regulate the country's greenhouse gases via mandatory emissions limits and a cap-and-trade system. Given the ongoing energy crisis, either of them may very well begin this process - Congress willing - as soon as they have taken office.

Another much-discussed topic on the campaign trail is innovation. Americans increasingly sense that their country is losing its competitive edge. Both McCain and Obama regularly talk about how re-investing in fundamental research can stimulate homegrown breakthroughs and bolster the flagging economy. And both candidates seem to be at least moderately sincere in their pledges to improve funding for the nation's basic-science agencies - although how those promises will translate to reality remains to be seen, especially as McCain has talked about a year-long freeze on all domestic discretionary spending, which would include science.

The outlook for other areas of science is even less clear. In the case of stem-cell research, Obama has vowed to lift the Bush administration's restrictions on federally funded research into human embryonic stem cells. McCain, too, voted to end such restrictions when the issue arose in the Senate, but in the heat of the campaign, he now refuses to say whether he would lift the ban as president. Instead, he emphasizes research on adult or induced pluripotent stem cells in place of human embryonic ones. This could spell dire news for the country's stem-cell biologists, many of whom have been driven

overseas or into privately or state-funded parallel enterprises to continue their work.

The most worrying thing about a McCain presidency is not so much a President McCain as a Vice-President Palin. Sarah Palin, Alaska's governor and McCain's running mate, opposes all research into human embryonic stem cells. She is a creationist. And until lately, at least, she has been a sceptic of human-created climate change - a disquieting thought, as Palin recently said that energy will be "her baby" in the White House, thanks to her previous service as chair of the Alaska state oil and gas commission.

What is still unclear is how Palin's views

"No matter who wins, the current administration's 8-year-long pattern of denial and footdragging will end." will reconcile with McCain's. McCain has courageously bucked his party's more parochial viewpoints in the past, as when he fought for a cap-and-trade system long before it was politically popular. But his selection of Palin as a running mate suggests a new-found willingness to pander to his party's far-right wing.

Contrast that with Obama's statement on page 448, in which Nature asked him about the teaching of intelligent design in science classes. It is not easy to address students' questions about evolution without falling prey to the false notion of 'teaching the controversy', as the Royal Society's director of education discovered last week in a public-relations meltdown (see 'Creation and classrooms'). But Obama could not be more clear: "I do not believe it is helpful to our students to cloud discussions of science with non-scientific theories like intelligent design that are not subject to experimental scrutiny," he wrote.

The emerging economic crisis has made a trillion-dollar bailout of US banks almost certain. Thus, much as the campaign may point to improved government attitudes toward science, researchers should hold out little hope for more funds for anything but the new president's very highest priorities.

\section{Creation and classrooms}

\section{Better to confront superstition with science than to disregard the superstitious.}

\footnotetext{
The headlines were damning. "Leading scientist urges teaching of creationism in schools," proclaimed Britain's The Times newspaper on 12 September, echoing the headlines appearing that day in numerous other British media. The stories asserted that Michael Reiss, a biologist and educational researcher, an ordained Anglican minister and (at the time) the education director of the Royal Society, had explicitly advocated that state-school biology classes teach creationism.
}

The reports were wrong. Speaking at the British Association for the Advancement of Science's annual Festival of Science on 11 September, Reiss had articulated - as he had many times before - a view consistent with the Royal Society's official position: when students from a creationist background raise the issue in class, the teacher should explain why creationism is not science and why evolution is. Nevertheless, on 16 September the society announced Reiss's departure, arguing that the media's misinterpretation had "led to damage to the society's reputation" (see page 441).

Nature was not privy to the conversations between the reporters and editors responsible for this story, so we will leave it to them to consider how such a gross misrepresentation could have happened, and what lessons to draw from it. Nor was Nature privy to the Royal Society's internal deliberations about Reiss, so we will leave it to the 